RAD Conference Proceedings, vol. 2, pp. 149-154, 2017

www.rad-proceedings.org

\title{
STRUCTURAL AND OPTICAL PROPERTIES OF CdTe THIN FILMS OBTAINED BY ELECTRODEPOSITION
}

\author{
Atanas Tanushevski*, Dragan Sokolovski \\ Institute of Physics, Faculty of Natural Sciences and Mathematics, \\ University “Sts. Cyril and Methodius”, Skopje, Republic of Macedonia
}

\begin{abstract}
Thin films of CdTe have been obtained by electrodeposition in the presence of tartaric acid on fluorinedoped tin oxide (FTO)-coated glass substrates, under a constant voltage of $1.4 \mathrm{O} \mathrm{V}$. In order to determine the deposition parameters of CdTe, cyclic voltammetry has been performed. The films were annealed at $T=200{ }^{\circ} \mathrm{C}, T=$ $300^{\circ} \mathrm{C}, T=400^{\circ} \mathrm{C}$ and $T=450^{\circ} \mathrm{C}$, in air atmosphere. The $X$-ray diffractograms show that the films obtained at $90^{\circ} \mathrm{C}$ are nanocrystal with cubic structure and with grain size of $6 \mathrm{~nm}$. The thermal treatment of CdTe films contributes to grain growth and obtaining polycrystalline films. Atomic Force Microscope shows that the films are smooth and uniform with columnar grains. The optical properties of the CdTe films have been investigated by measurements of wavelength-dependent transmission. The optical band gap of as-deposited films is $1.48 \mathrm{eV}$ and is decreasing up to $1.45 \mathrm{eV}$, for films annealed at temperature of $300{ }^{\circ} \mathrm{C}$, and increasing again at temperature of $45 \mathrm{O}^{\circ} \mathrm{C}$. $\mathrm{Lastly}^{\mathrm{SnO} \mathrm{S}^{-}}$ CdS-CdTe-electrolyte-graphite type photoelectrochemical solar cells have been made, using the o.1 M NaOH-Na$a_{2} S_{x}$ electrolyte. From the measured current-voltage characteristics, open circuit voltage of $V_{o c}=500 \mathrm{mV}$ and short circuit current of $I_{s c}=1.2 \mathrm{~mA} / \mathrm{cm}^{2}$ have been determined.
\end{abstract}

Key words: Cadmium Telluride, electrodeposition, tartaric acid, photochemical solar cells

DOI: $10.21175 /$ RadProc.2017.30

\section{INTRODUCTION}

Lately, photoelectrochemical cells, which possess certain advantages over cells with $\mathrm{p}-\mathrm{n}$ junction, are more and more attractive. Photoelectrochemical cells can be deposited on large area, defects in the crystal structure of individual layers are not significant, and their efficiency approaches diode solar cells [1]. Lately, materials that do not harm the environment ecologically are researched, yet solar cells based on CdTe are efficient and stable [2, 3]. CdTe is a semiconducting compound used in the production process of $\mathrm{PV}$, due to the high value of the absorption coefficient and the optimal width of the band gap of 1.5 $\mathrm{eV}$. CdTe in the shape of thin film can be polycrystalline or nanocrystalline, which can contribute towards the change of its characteristics [4]-[6]. Different methods are used for the preparation of thin films of CdTe, including electrodeposition [4], [7], [8], magnetron sputtering [9], [10], thermal evaporation [5], [11], close space sublimation [12] - [14] and others [15], [16].

Semiconducting detectors of X-ray and radioactive emissions are attractive to medicine and nuclear medicine [17]. It is important to develop digital emission detectors that will have great sensitivity and resolution in comparison to gas and scintillation detectors. For that purpose, semiconducting detectors of CdTe and CdZnTe are researched, and they should detect X-ray and gamma radiation.

Previous studies have been directed towards obtaining detectors with an absorption layer of CdTe, created on the basis of the existence of a p-n transition and electrodes for collecting the generated carriers. However, photoelectrochemical cells have recently appeared, where for transfer of holes liquid electrolyte or electrolyte in liquid state is used [18] - [22].

\section{MATERIALS AND METHODS}

Before a thin film of CdTe is deposited, a thin film of CdS is deposited over substrates of $\mathrm{SnO}_{2}$, with resistance of $20 \mathrm{Ohms} / \mathrm{square}$. CdS thin films were obtained via chemical bath deposition of alkaline aqueous solution $\mathrm{CdCl}_{2}$ that is complexed with $\mathrm{NH}_{4} \mathrm{OH}$ of the thiourea that helps in obtaining sulfur anions, and the reaction takes place in the presence of $\mathrm{NH}_{4} \mathrm{~F}$ as a buffer. The CdS films that were deposited after 5 minutes are thermally treated in air at a temperature of $400{ }^{\circ} \mathrm{C}$ [23] for better crystallization.

Cadmium telluride thin films were deposited via the method of electrodeposition on substrates with a $\mathrm{SnO}_{2}$ layer and substrates with $\mathrm{SnO}_{2}$-CdS layers. For electrodeposition of CdTe, an aqueous solution of 
cadmium sulfate, tellurium dioxide and tartaric acid is used.

For that purpose, the water solution was composed of $0.2 \mathrm{M} \mathrm{CdSO}_{4}$ and $0.8 \mathrm{mM} \mathrm{Na} \mathrm{TeO}_{3}$, while the solution temperature was $90{ }^{\circ} \mathrm{C}$ and the acidity of the solution was adjusted using tartaric acid, to the value of $\mathrm{pH}=2$. Transparent conductive film of $\mathrm{SnO}_{2}$ deposited on glass and substrates with layers of $\mathrm{SnO}_{2}$-CdS was used for working electrode, whereas a graphite rod was used for the counter electrode. The voltage of the working electrode opposed to the one of the counter electrode was $-1.4 \mathrm{~V}$ and it was maintained constant during the deposition. The time of deposition was 10 minutes on $\mathrm{SnO}_{2}$ substrates and 1.5 hour on substrates with layers of $\mathrm{SnO}_{2}$-CdS. CdTe thin film was obtained by electrodeposition, and in the cathode the following reaction took place [24]:

$$
2 \mathrm{Cd}+\mathrm{HTO}_{2}^{+}+3 \mathrm{H}^{+} \rightarrow 2 \mathrm{Cd}^{2+}+\mathrm{Te}+2 \mathrm{H}_{2} \mathrm{O}
$$

The films electrodeposited for 10 minutes on $\mathrm{SnO}_{2}$ substrates and 1.5 hour on substrates with layers of $\mathrm{SnO}_{2}$-CdS have good adhesion, uniform and without holes .

CdTe thin film deposited by electrolysis on $\mathrm{SnO}_{2}$ substrates was thermally treated in air at temperatures of $T=200^{\circ} \mathrm{C}, T=300^{\circ} \mathrm{C}, T=400^{\circ} \mathrm{C}$ and $T=450^{\circ} \mathrm{C}$, in order to examine the influence of temperature on its structural and optical properties. On the other hand, CdTe film obtained by electrodeposition on substrates with layers of $\mathrm{SnO}_{2}-\mathrm{CdS}$ was thermally treated in air at a temperature of $T=400{ }^{\circ} \mathrm{C}$.

For the characterization of the chemical reactions during CdTe electrodeposition, a cyclic voltammetry was created using two electrodes, wherein $\mathrm{SnO}_{2}$ film was used as the working electrode and a graphite rod was used as the counter electrode. Additionally, for measuring the $I-V$ characteristics, PM $8272 \mathrm{XYt}$ Recorder Philips and Wavetek Model 134 Sweep Generator are used.

The crystal structure of the films was studied using $\mathrm{X}$-ray diffraction (XRD) measurements obtained with a Rigaku Ultima IV powder X-ray diffractometer, for $2 \theta$ in the range of $20^{\circ}-70^{\circ}$. As a radiation source we used $\mathrm{Cu}-\mathrm{K}_{\alpha}$ radiation with $\lambda=0.15418 \mathrm{~nm}$, obtained from a generator set at $40 \mathrm{kV}$ and a current of $40 \mathrm{~mA}$, with a scan rate of $2 \%$ min. The optical transmission spectra of the deposited thin films of CdTe was determined with a Varian Cary 50 spectrophotometer in order to determine the band gap energy, within the range of 400-900 $\mathrm{nm}$.

The AFM images of the surfaces of the films were taken with a Scanning Probe Microscope SPM-9700 operating in dynamic mode.

Photoelectrochemical cell type $\mathrm{SnO}_{2}$-CdS-CdTeelectrolyte-grafite was made using semiconducting electrode $\mathrm{SnO} 2-\mathrm{CdS}-\mathrm{CdTe}$ and graphite counter electrode, while for the electrolyte an aqueous solution of $0.1 \mathrm{M} \mathrm{NaOH}$ and $0.1 \mathrm{M} \mathrm{Na}_{2} \mathrm{~S}_{\mathrm{x}}$ was used. For lighting the photo electrochemical cell, the GRAFOSKOP-Šs 650, whose intensity is measured with the LUX-UV-IR Meter 666230 light meter, was used. The cells are illuminated from the front side of the glass- $\mathrm{SnO}_{2}-\mathrm{CdS}-$ CdTe- electrolyte-grafite, which is near to the edge of the civet. To measure the $I-V$ characteristics of photo electrochemical cells, we used a function generator
Iskra MA 3732, and then the cell is serially bound to the voltage source and the standard resistor, while the current and the voltage are measured using the PM 8272 XYt Recorder Philips.

\section{RESUltS AND DisCUSSION}

For the characterization of the conditions, the electrodeposition of CdTe films is made of cyclic voltammetry of aqueous solution of $0.2 \mathrm{M} \mathrm{CdSO}_{4}$ and $0.8 \mathrm{mM} \mathrm{Na}_{2} \mathrm{TeO}_{3}$, with the solution temperature at 90 ${ }^{\circ} \mathrm{C}$ and $\mathrm{pH}=2$. The voltage between the working electrode $\left(\mathrm{SnO}_{2}\right.$ film $)$ and the counter electrode (graphite) was changing from $+1.82 \mathrm{~V}$ to $-1.82 \mathrm{~V}$, at a scan rate of $40 \mathrm{mV} / \mathrm{s} \mathrm{[4],} \mathrm{[25].} \mathrm{Figure} 1$ shows that cadmium starts to deposit at cathode voltage of -0.90 $\mathrm{V}$, while the cathode voltage of $-1.4 \mathrm{~V}$ plateau occurs and therefore the latter was elected as the voltage for the electrodeposition of CdTe film. In fact, during deposition voltage of $-1.4 \mathrm{~V}$, a reduction of $\mathrm{Cd}^{2+}$ and $\mathrm{Te}^{4+}$ ions at the cathode occurs, and, as a result, a CdTe film starts creating on the cathode [25].

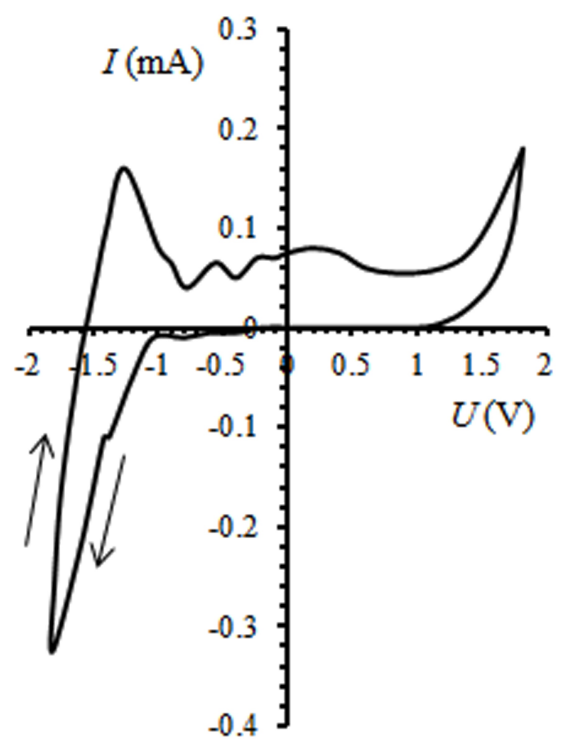

Figure 1. Cyclic voltammetry of as-deposited CdTe thin film

The crystal structure and composition of CdTe thin films were determined by x-ray diffraction spectra (Figure 2), which showed that the films obtained at 90 ${ }^{\circ} \mathrm{C}$ are nanocrystalline with cubic structure, while the annealed films are polycrystalline with a cubic structure. Since the films were deposited on the $\mathrm{SnO}_{2}$ film, the XRD spectrum shown in Figure 2 is compared to the diffraction spectrum of CdTe given on the JCPDS card 75-2086. Peaks that are not shown on the card refer to the diffraction spectrum of the $\mathrm{SnO}_{2}$ film and in order to be distinguishable they are marked in Figure 1. From the XRD diffraction pattern it can be concluded that at $2 \theta=23.76^{\circ}$ the highest peak is obtained, while it is a reflection of crystallographic plane (111) and the other peaks of $2 \theta=39.29^{\circ}, 46.44$ ${ }^{\circ}, 62.42^{\circ}$ correspond to planes (220), (311), (331), respectively. Thermal treatment of a CdTe film at temperatures of $T=200{ }^{\circ} \mathrm{C}$ and $T=300{ }^{\circ} \mathrm{C}$ increases the height of the peak $2 \theta=23.76^{\circ}$, while the $T=400$ 
${ }^{\circ} \mathrm{C}$ peak decreases and at $T=450{ }^{\circ} \mathrm{C}$ we have the highest peak compared to other temperatures.

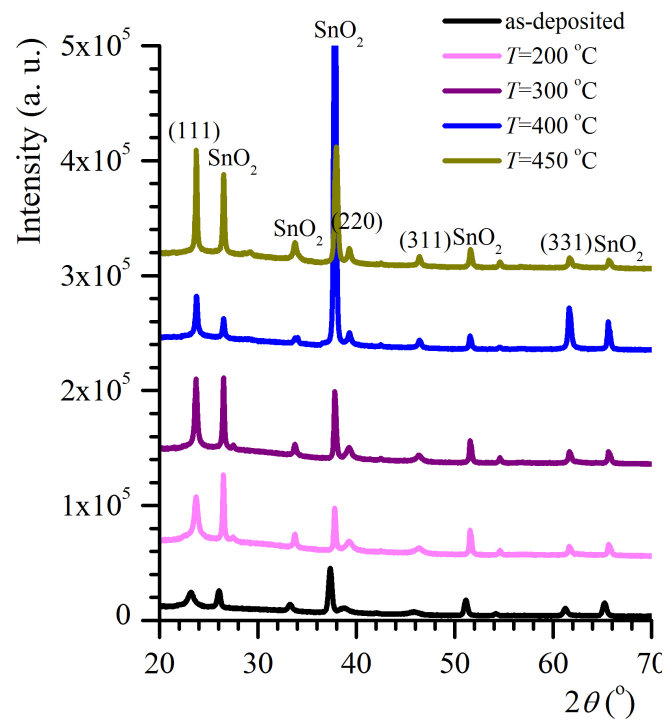

Figure 2. XRD pattern obtained from as-deposited and annealed CdTe thin films at different temperatures

In Figure 1, one can determine the size of the grains $D$ on CdTe thin films, which are as-deposited and thermally treated at different temperatures (Table 1). Depending on the height and width of the highest peak, the average size of the grains is determined and it is calculated using the Debye-Scherer relation [26]:

$$
D=\frac{0.9 \lambda}{\beta \cos \theta}
$$

where $\lambda$ is wavelength, $\beta$ is broadening of diffraction line measured at half-maximum intensity and $\theta$ is angle.

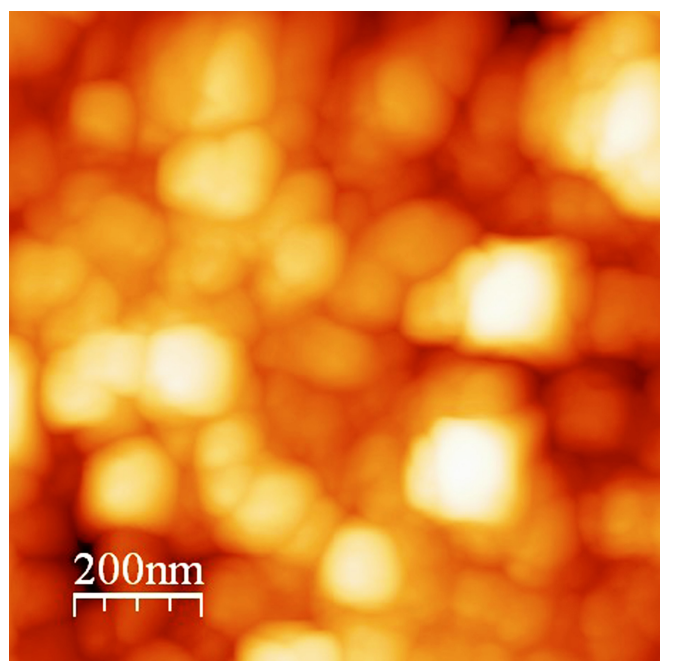

Figure 3. AFM image of the surface of a CdTe film annealed at a temperature of $450^{\circ} \mathrm{C}$

The morphology of films was determined by AFM (atomic force microscopy), whereby the film surface studied was $1 \mu \mathrm{m} \times 1 \mu \mathrm{m}$. The size of the grains determined by AFM images are in accordance with the results obtained from XRD measurements (Figure 3).

For determining the optical band gap of CdTe thin films, measurements of the transmission in the wavelength range of $400-900 \mathrm{~nm}$ (Figure 4) were made.

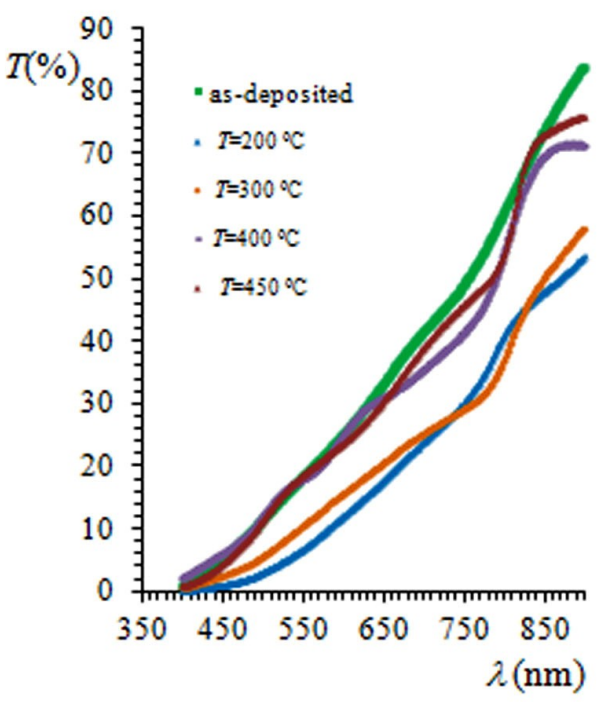

Figure 4. Transmission spectra of the CdTe thin films as a function to the substrate temperature

Figure 4 shows that the transmission is sharply rising at wavelengths over $770 \mathrm{~nm}$ to $850 \mathrm{~nm}$. This means that the value of the band gap of CdTe should be set in this range of wavelengths.

However, for determining the width of the band gap and the type of transitions of the electrons between the valence and conduction band, it is necessary to determine the absorption coefficient (Figure 5), given by the relation [27]:

$$
\alpha=\frac{1}{d} \ln \left(\frac{1}{T}\right)
$$

The optical band gap is calculated using the relation:

$$
\alpha h v=A\left(h v-E_{g}\right)^{\frac{1}{2}} n
$$

where $A$ is a parameter that depends on the transition probability, $\alpha$ is the absorption coefficient, $h$ is the Plank constant, $E_{\mathrm{g}}$ is the optical bandgap energy, $v$ is the frequency of photons and $n$ is an index that can assume values of $1 / 2$ for the direct allowed transitions. The optical bandgap $E_{\mathrm{g}}$ of the films can be determined by using a graphic presentation of $(\alpha h v)^{2}=f(h v)$ and from the intersection of the straight part of the curves with the $\mathrm{x}$-axis (Figure 6).

The derived results show that the band gap $E_{\mathrm{g}}$ of asdeposited and thermally treated CdTe film varies from $1.45 \mathrm{eV}$ to $1.48 \mathrm{eV}$, and it decreases with the increase in temperature to $300{ }^{\circ} \mathrm{C}$, whereas over this temperature there is a trend of growth (Table 1 ). 
Table 1. The estimated values of grain size and the bandgap energy as a function of substrate temperature

\begin{tabular}{|l|c|c|}
\hline CdTe & $D(\mathrm{~nm})$ & $E_{\mathrm{g}(\mathrm{op})}(\mathrm{eV})$ \\
\hline as- deposited & 6 & 1.48 \\
$200{ }^{\circ} \mathrm{C}$ & 18 & 1.46 \\
$300^{\circ} \mathrm{C}$ & 40 & 1.45 \\
$400^{\circ} \mathrm{C}$ & 38 & 1.47 \\
$450^{\circ} \mathrm{C}$ & 74 & 1.47 \\
\hline
\end{tabular}

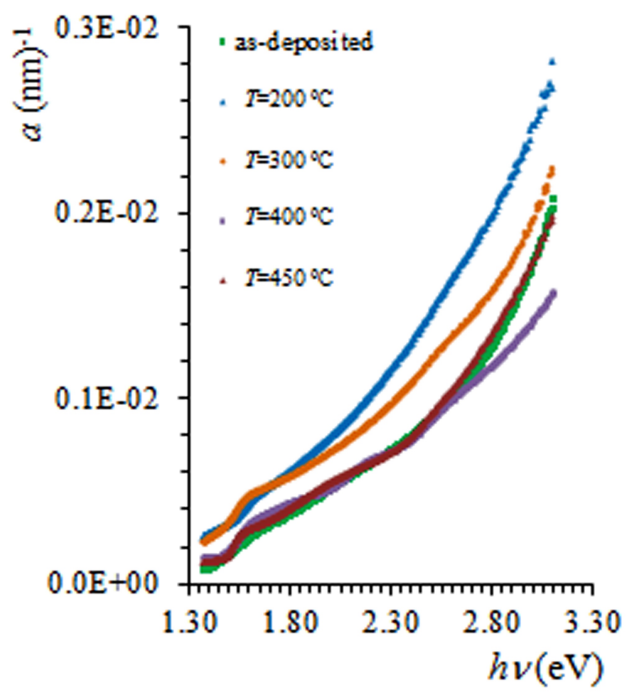

Figure 5. Dependence of absorption coefficient versus photon energy, and as a function to the substrate temperature

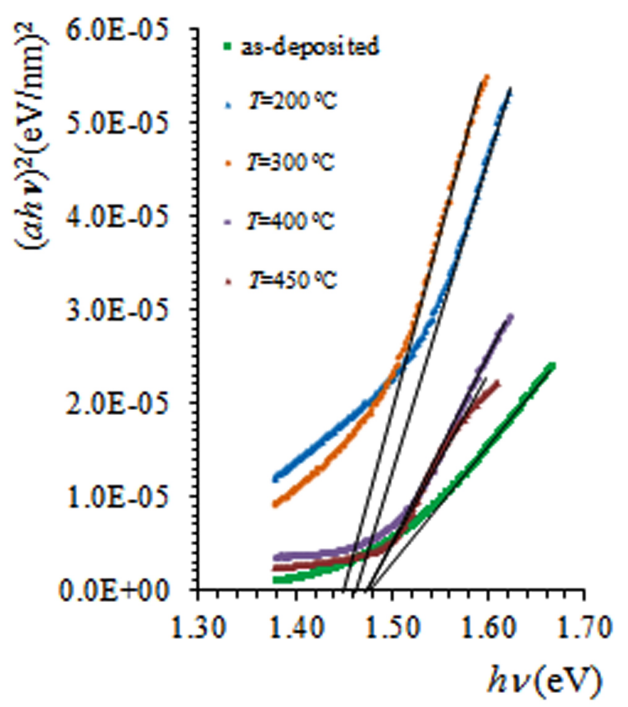

Figure 6. The dependence of $(\alpha h v)^{2}$ on the photon energy $(h v)$ of the CdTe thin films at different substrate temperatures for direct allowed transitions

The determination of the type of electrical conductivity of electrodeposited CdTe thin film is performed by measuring the voltage between the glass/FTO/CdTe-electrolyte ( $\left.0.1 \quad \mathrm{M} \quad \mathrm{Na}_{2} \mathrm{~S}_{2} \mathrm{O}_{3}\right)$ and graphite. Depending on the difference of voltage of the PEC cell in dark and illumination of $100 \mathrm{~mW} / \mathrm{cm}^{2}$ the type of CdTe thin film is defined. Figure 7 shows that the CdTe thin film is n-type when the voltage is higher than $-0.85 \mathrm{~V}$, while at voltage of $1.5 \mathrm{~V}$, the CdTe thin film is close to stoichiometric semiconductor. For voltage exceeding $1.5 \mathrm{~V}$ the CdTe thin film becomes strong doped n-type [28].

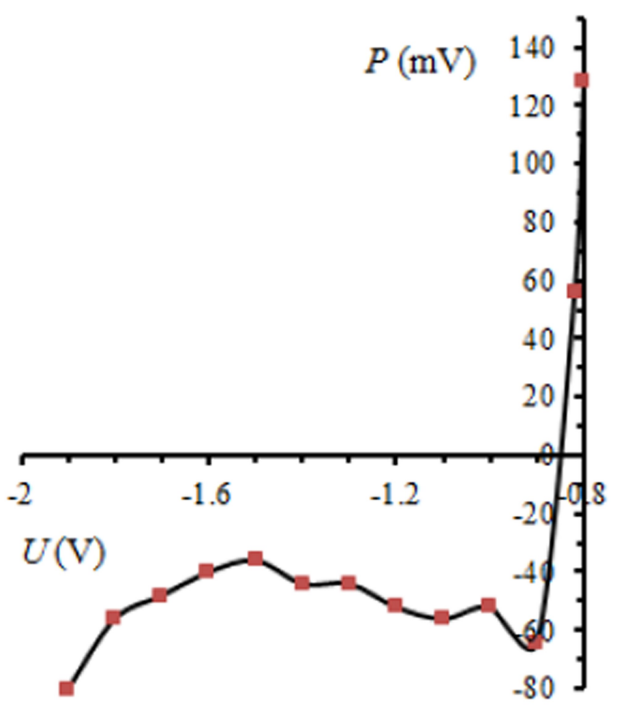

Figure 7. The PEC signal of the as-deposited CdTe thin film

Photoelectrochemical cells of the type $\mathrm{SnO}_{2}-\mathrm{CdS}-$ CdTe-electrolyte-grafite were made, where an aqueous solution of $0.1 \mathrm{M} \mathrm{NaOH}-0.1 \mathrm{M} \mathrm{Na}_{2} \mathrm{~S}_{\mathrm{x}}$ was used as the electrolyte.

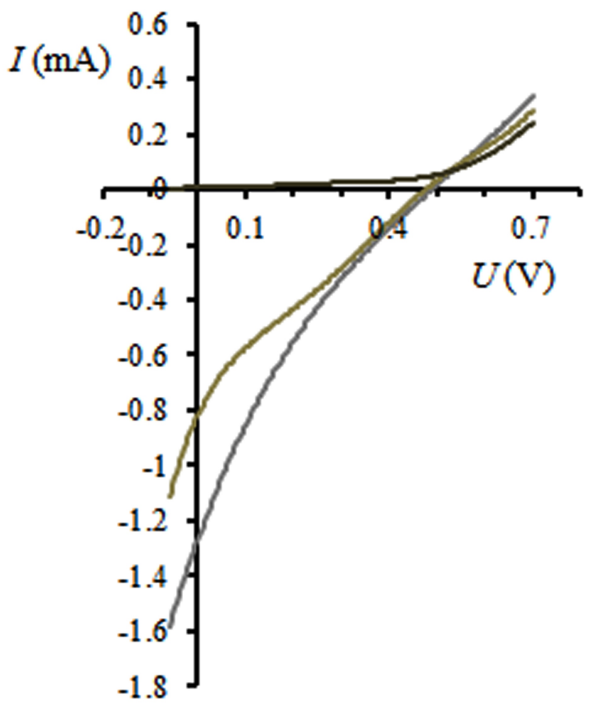

Figure 8. $I-V$ characteristics of SnO2-CdS-CdTe-graphite solar cell

For characterization of photoelectrochemical cell its $I-V$ characteristics are measured in dark and light with light intensity of $50 \mathrm{~mW} / \mathrm{cm}^{2}$ and $100 \mathrm{~mW} / \mathrm{cm}^{2}$ (Figure 8). In lighting, the $\mathrm{SnO}_{2}$-CdS-CdTe photoanode voltage 
is higher than the voltage of the graphite counter electrode.

Using the measured $I-V$ characteristics, the efficiency of the cell is determined with the following equation [29]:

$$
\eta=\frac{V_{m} I_{m}}{P \cdot A}=\frac{F F \cdot I_{s c} V_{o c}}{P \cdot A}=
$$

where $P$ is the intensity of the light, $F F$ is the filling factor, $A$ is the surface of the solar cell, $I_{\mathrm{sc}}$ is the shortcircuit current and $V_{\text {oc }}$ is the open-circuit voltage. Furthermore, the filling factor is determined by the equation:

$$
F F=\frac{V_{\max } \cdot I_{\max }}{V_{\mathrm{oc}} \cdot I_{\mathrm{sc}}}
$$

where $I_{\max }$ is the maximum current and $V_{\max }$ is the maximum voltage, in a particular point of $I-V$ characteristic in which we have the maximum efficiency of the cell. When the lighting of the cell has the light intensity of $100 \mathrm{~mW} / \mathrm{cm}^{2}$, the efficiency of the photo electrochemical cell is $0.12 \%$. The liquid electrolyte used in photoelectrochemical cell can be replaced with an electrolyte of solid CuSCN [15], which will contribute to the stability and durability of the cell and its use as a radiation detector.

\section{CONCLUSIONS}

CdTe thin film has been electrodeposited on glass substrates covered with a transparent conductive film of $\mathrm{SnO}_{2}$, at constant voltage of 1,40 V. XRD diffraction patterns of as-deposited and thermally treated films show that the films have a cubic crystal structure. The average size of the grains of $74 \mathrm{~nm}$ is greatest for films that have a thermal treatment at a temperature of $T=$ $450{ }^{\circ} \mathrm{C}$. The optical band gap is reduced to a value of $1.45 \mathrm{eV}$ during a thermal treatment at a temperature of $T=300{ }^{\circ} \mathrm{C}$, and higher temperatures increase it to 1.47 $\mathrm{eV}$.

Photoelectrochemical cells of the type $\mathrm{SnO}_{2}$-CdSCdTe-electrolyte-grafite were made with the electrolyte $0.1 \mathrm{M} \mathrm{NaOH}-0.1 \mathrm{M} \mathrm{Na}_{2} \mathrm{~S}_{\mathrm{x}}$. The efficiency of the cells is $0.12 \%$ and can be increased using solid electrolyte and thermal treatment of the layers at a temperature greater than $T=450^{\circ} \mathrm{C}$.

\section{REFERENCES}

1. A. V. Kokate, M. R. Asabe, P. P. Hankare, B. K. Chougule, "Effect of annealing on properties of electrochemically deposited CdTe thin films," Journal of Physics and Chemistry of Solids, vol. 68, no. 1, pp. 53-58, 2007

DOI: $10.1016 /$ j.jpcs.2006.09.018

2. D. L. Bätzner, A. Romeo, M. Terheggen, M. Döbeli, H. Zogg, A. N. Tiwari, "Stability aspects in CdTe/CdS solar cells," Thin Solid Films, vol. 451-452, pp. 536543, Mar. 2004. DOI: 10.1016/j.tsf.2003.10.141

3. A. K. Fedotov, A. A. Ronassi et al., "Electrical, photoelectrical, and photoelectrochemical properties of electrodeposited CdTe films subjected to high-energy irradiation," Thin Solid Films, vol 519, pp. 7149-7152, Aug. 2011.
DOI: 10.1016/j.tsf.2010.12.221

4. I. M. Dharmadasa, P. A. Bingham, O. K. Echendu et al., "Fabrication of CdS/CdTe-Based Thin Film Solar Cells Using an Electrochemical Technique," Coatings, vol. 4 no. 3, pp. 380-415, Jun. 2014 DOI: $10.3390 /$ coatings 4030380

5. S. Lalitha, S. Zh. Karazhanov, P. Ravindran et al., "Electronic structure, structural and optical properties of thermally evaporated CdTe thin films," Physica B, vol. 387, no. 1-2, pp. 227-238, Jan. 2007. DOI: $10.1016 /$ j.physb.2006.04.008

6. Xian-Feng Gao, Hong-Bo Li, Wen-Tao Sun et al., "CdTe Quantum Dots-Sensitized $\mathrm{TiO} 2$ Nanotube Array Photoelectrodes," J. Phys. Chem. C, vol. 113, no. 18, pp. 7531-7535, Apr. 2009. DOI: 10.1021/jp810727n

7. X. Mathew, P. J. Sebastian, A. Sanchez, J. Campos, "Structural and opto-electronic properties of electrodeposited CdTe on stainless steel foil," Solar Energy Materials \& Solar Cells, vol. 59, no. 1-2, pp. 99114, Sep. 1999. DOI: 10.1016/So927-0248(99)00035-5

8. M. E. Calixto, J. C. McClure, V. P. Singh, A. Bronson, P. J. Sebastian, X. Mathew, "Electrodeposition and characterization of CdTe thin films on Mo foils using a two voltage technique," Solar Energy Materials \& Solar Cells, vol. 63, no. 4, pp. 325-334, Aug. 2000. DOI: 10.1016/So927-0248(00)00052-0

9. S. Marsillac, V. Y. Parikh, A. D. Compaan, "Ultra-thin bifacial CdTe solar cell," Solar Energy Materials \& Solar Cells, vol. 91, no. 15-16, pp. 1398-1402, Sep. 2007.

DOI: 10.1016/j.solmat.2007.04.025

10. N. Romeo, A. Bosio, R. Tedeschi, A. Romeo, V. Canevari, "A highly efficient and stable $\mathrm{CdTe} / \mathrm{CdS}$ thin film solar cell," Solar Energy Materials \& Solar Cells, vol. 58, no. 2, pp. 209- 218, Jun. 1999. DOI: 10.1016/So927-0248(98)00204-9

11. A. Romeo, G. Khrypunov, F. Kurdesau et al., "Highefficiency flexible CdTe solar cells on polymer substrates," Solar Energy Materials \& Solar Cells, vol. 90, no. 18-19, pp. 3407-3415, Nov. 2006 DOI: $10.1016 /$ j.solmat.2005.09.020

12. A. Bosio, N. R.S. Mazzamuto, V. Canevari, "Polycrystalline CdTe thin films for photovoltaic applications," Progress in Crystal Growth and Characterization of Materials, vol. 52, no. 4, pp. 247279, Dec. 2006. DOI: 10.1016/j.pcrysgrow.2006.09.001

13. Q. Jiang, D. P. Haliday, B. K. Tanner et al., "Thick epitaxial CdTe films grown by close space sublimation on Ge substrates," J. Phys. D: Appl. Phys., vol. 42, no. 1, pp. 012004-1 - 012004-4, Dec. 2008. DOI: $10.1088 / 0022-3727 / 42 / 1 / 012004$

14. N. A. Shah, A. Ali, Z. Ali, A. Maqsood, A. K. S. Aqili, "Properties of Te-rich cadmium telluride thin films fabricated by closed space sublimation technique," Journal of Crystal Growth, vol. 284, no. 3-4, pp. 477485, Nov. 2005.

DOI: 10.1016/j.jcrysgro.2005.08.005

15. R. Tena-Zaera, T. A. Katty, S. Bastide et al., "ZnO/CdTe/CuSCN, a promising heterostructure to act as inorganic eta-solar cell," Thin Solid Films, vol. 483, no. 1-2, pp. 372- 377, Jul. 2005. DOI: $10.1016 /$ j.tsf.2005.01.010

16. M. G. Panthani, J. M. Kurley, R. W. Crisp et al., "High Efficiency Solution Processed Sintered CdTe Nanocrystal Solar Cells: The Role of Interfaces," Nano Lett., vol. 14, no. 2, pp. 670-675, Dec. 2013.

DOI: $10.1021 / \mathrm{nl} 403912 \mathrm{~W}$

PMid: 24364381

17. S. Del Sordo, L. Abbene, E. Caroli et al., "Progress in the Development of CdTe and CdZnTe Semiconductor Radiation Detectors for Astrophysical and Medical Applications," Sensors, vol. 9, no. 5, pp. 3491-3526, May 2009. 
DOI: $10.3390 /$ s90503491

PMid: 22412323

PMCid: PMC3297127

18. R. K. Pandey, S. Mishra, S. Tiwari, P. Sahu, B. P. Chandra, "Comparative study of performance of CdTe, CdSe and CdS thin films-based photoelectrochemical solar cells," Solar Energy Materials \& Solar Cells, vol. 6o, no. 1, pp. 59-72, Jan. 2000.

DOI: 10.1016/So927-0248(99)00063-X

19. K. Uosaki, M. Takahashi, H. Kita, "The photoelectrochemical Behaviour of electrochemically deposited CdTe films," Electrochimica acta, vol. 29, no. 2, pp 279-281, Feb. 1984.

DOI: $10.1016 / 0013-4686(84) 87060-7$

20. P. V. Kamat, K. Tvrdy, D. R. Baker, J. G. Radich, "Beyond photovoltaics: semiconductor nanoarchitectures for liquid-junction solar cells," Chem. Rev., vol. 110, no. 11, pp. 6664-6688, Oct. 2010. DOI: $10.1021 /$ cr100243p PMid: 20973544

21. X. F. Gao, H. B. Li, W. T. Sun et al., "CdTe Quantum Dots-Sensitized TiO2 Nanotube Array Photoelectrodes," J. Phys. Chem. C, vol. 113, no. 18, pp. 7531-7535, Apr. 2009. DOI: $10.1021 /$ jp810727n

22. Zh. Li, W. Luo, M. Zhang, J. Feng, Zh. Zou, "Photoelectrochemical cells for solar hydrogen production: current state of promising photoelectrodes, methods to improve their properties, and outlook," Energy \& Environmental Science, vol. 6, no. 2, pp. 347-370, Dec. 2012. DOI: 10.1039/C2EE22618A

23. N. Novkovski, A. Tanusevski, D. Gracin, "Refined analysis of absorption spectra of CdS thin films," J. Phys. D: Appl. Phys., vol. 48, no. 39, pp. 395105-1 395105-9, Sep. 2015.

DOI: $10.1088 / 0022-3727 / 48 / 39 / 395105$
24. M. P. R. Panicker, M. Knaster, F. A. Kroger, "Cathodic Deposition of CdTe from Aqueous Electrolytes," J. Electrochem. Soc., vol. 125, no. 4, pp. 566-572, 1978. DOI: 10.1149/1.2131499

25. A.Y. Shenouda, El Sayed M. El Sayed, "Electrodeposition, characterization and photo electrochemical properties of CdSe and CdTe," Ain Shams Engineering Journal, vol. 6, no. 1, pp. 341-346, Mar. 2015.

DOI: 10.1016/j.asej.2014.07.010

26. M. M. El-Nahass, G. M. Youssef, S. Z. Noby, "Structural and optical characterization of CdTe quantum dots thin films," Journal of Alloys and Compounds, vol. 604, pp. 253-259, Aug. 2014. DOI: 10.1016/j.jallcom.2014.03.104

27. J.P. Enríquez, "Effects of annealing time and temperature on structural, optical and electrical properties of $\mathrm{CdS}$ films deposited by CBD," Chalcogenide Letters, vol. 10, pp. 45-53, Feb. 2013. Retrieved from: http://chalcogen.ro/45 Pantoja.pdf Retrieved on: Feb. 12, 2017

28. H. I. Salim, V. Patel, A. Abbas, J. M. Walls, I. M. Dharmadasa, "Electrodeposition of CdTe thin films using nitrate precursor for applications in solar cells," J. Mat. Sci: Materials in Electronics, vol. 26, no. 5, pp. 3119-3128, May 2015. DOI: $10.1007 / \mathrm{s} 10854-015-2805-\mathrm{x}$.

29. S. J. Lade, M. D. Uplane, C. D. Lokhande, "Photoelectrochemical properties of CdX (XDS, Se, Te) films electrodeposited from aqueous and non-aqueous baths," Materials Chemistry and Physics, vol. 68, no. 1-3, pp. 36-41, Feb. 2001

DOI: 10.1016/So254-0584(00)00280-7 